\title{
Correlation of Serum Concentrations of Soluble Thrombomodulin, Soluble Vascular Cell Adhesion Molecule-1, Intracellular Adhesion Molecule -1 And E-Selectin In Patients With Systemic Lupus Erythematosus
}

\author{
Malak., A. Mohsen*, Magda.A.Gamil*,Maha. I.Shehata* \\ Boshra.H,El Zawahry **and Salwa.S.I.Afifi***
}

\begin{abstract}
Clinical Biochemistry, ${ }^{*}$ Microbiology and**Physiology Departments. Faculty of Medicine for Girls and *** Microbiology Department Faculty of Pharmacy, Al- Azhar University, Cairo, Egypt.
\end{abstract}

\begin{abstract}
:
To date no specific serological parameters are available to assess disease activity in systemic lupus erythematosus (SLE). The objective of this study was to correlate serum levels of thrombomodulin (TM), intracellular adhesion molecule-1 sICAM-1, vascular cell adhesion molecule-1 sVCAM-1, and E-selectin with standard laboratory tests and clinical indices of disease activity in 40 patients with SLE and 20 apparently healthy persons as controls. According to British Isles Lupus Assessment Group (BILAG) disease activity index, the 40 patients were divided into two groups, the first consisted of 22 with active disease, and the second consisted of 18 patients with inactive SLE. Serum STM, sICAM-1, sVCAM-I, and Eselectin were measured in their sera, using enzyme linked immuonosorbent assay (ELISA) technique.C-reactiv protein (CRP), Erythrocyte sedimentation rates (ESR) and serum creatinines were measured by standard laboratory tests. Total leukocytic count and hemoglobin concentration were detected by coulter counter. Levels of sTM and sVCAM were highly elevated in the group of patients with active SLE as compared to the inactive one $(\mathrm{P}<0.0005)$ while sICAM-1 levels were moderately elevated $(\mathrm{P}<0.005)$. E-selectin was poorly correlated with disease activity in SLE (P>0.05). In SLE, the BILAG disease activity index, ESR and serum creatinine correlated best with STM, sVCAM-1 and E-selectin levels while there was a weak association between CRP levels and the adhesion molecules, and no correlation between CRP level and disease activity.

In conclusion, sTM and sVCAM were the most important serological indices of disease activity in SLE and might be valuable serological parameters for monitoring therapy.
\end{abstract}

\section{Introduction:-}

Systemic lupus erythematosus (SLE) is an autoimmune disease of unknown aetiology affecting multiple organ systems .The role of vascular injury in the pathogenesis of SLE has been well described \{Belmont et al ; 1999, Cronstein et al; 1999\}. Circulating immune complexes of auto antibodies and selfantigens are deposited in the vascular walls of SLE patients and activate the complement pathways .The resulting complement products stimulate leucocytes to injure the vascular endothelium, leading to blood vessel destruction and organ injury (e.g. glomerulonephritis and vasculitis).It has been suggested that expression of adhesion molecules primes the vascular endothelium for subsequent injury, as reflected by increased release of thrombomodulin (TM) into the circulation (Belmont et al; 1997 , Boehme et al ;2000).

TM is a cell-surface glycoprotein located at the luminal surface of the vascular endothelium and acts as a membrane bound; high-affinity thrombin receptor (Dittman and Majerus; 1990).It 
down- regulates coagulation by acting as a cofactor of thrombin- catalyzed activation of protein $\mathrm{C}(\mathrm{PC})$. The binding of thrombin to TM increases its ability to activate $\mathrm{PC}$ at least 1000 fold (Esmon et al; 1982). Activated PC inhibits coagulation by inactivation of coagulation factors $\mathrm{Va}$ and VIIIa in the presence of cofactor protein $\mathrm{S}(\mathrm{PS})$ and the $\mathrm{C} 4$ binding protein. Thus, TM plays a major role in the regulation of intravascular coagulation (Scarpati and Sadler; 1990). TM is released mainly due to endothelial cell damage and not due to physiological activation and it is present in the circulation in its degraded forms (Ishii et al; 1991). Its soluble form (sTM) is detected in plasma and urine after endothelial injury, and has been reported as a predictor of thrombotic crisis (Ishii et al ; 1990) .TM has been used widely as a marker of micro vascular endothelial injury and thrombotic events in various diseases, such as disseminated intravascular coagulation (Endo et al ;1995), multiple sclerosis (Tsukada et al ;1995) rheumatic diseases (Ohdama et al ; 1994) and vasculitis (Boehme et al ;2000). Thus sTM elevation seems to be a promising marker for disease activity in SLE, nephritis and vasculitis (Boehme et al ;1994,Kotajima ; et al 1997, Boehme et al ;2000).

Adhesion molecules, including vascular cell adhesion molecule-1 (VCAM1) E-selectin and intracellular adhesion molecule-1(ICAM-1), are essential for cellular interactions, and play an important role in the activation and adhesion of cells (Springer;1994). Up-regulated expression of adhesion molecules on leukocytes and vascular endothelium leads to the adherence of inflammatory cells to the blood vessel wall and their subsequent extravasation (Cronstein et al; 1999). Soluble adhesion molecules have been detected in plasma and thus serve as useful markers of both leukocyte and endothelial cell activation in different diseases, such as autoimmune disorders, including rheumatoid arthritis, vasculitis and SLE (Horak et al; 2001).

Intracellular adhesion molecule-1 (ICAM-1, CD102) and vascular cell adhesion molecule-1(VCAM-1, CD106) are both members of immunoglobulin super gene family (Christian et al; 1998). ICAM1 is constitutively expressed on endothelial cells and on a variety of $\mathrm{B}$ and $\mathrm{T}$ lymphoblastoid cell lines (Fougerolles et al; 1991). The ligand for ICAM-1on other cells is leukocyte function- associated antigen-I (IFA-1, CD II a /CD18) (Dransfield et al; 1990). It is involved in cell-cell adhesive interaction of the immune system. It is a cytokine- induced glyco -protein involved in recruitment of cells into tissues undergoing inflammatory responses.

VCAM-1 is a seven domain member of the immunoglobulin super gene family. It is constitutively expressed at low levels by bone marrow stromal cells (juneje et al; 1993). It can be induced on vascular endothelial cells and follicle dendritic cells and up regulated on marrow stromal cells by cytokines such as IL-1and TNF$\alpha($ Bachner et al; 1995). The ligand for VCAM-1 is very late activation antigen-4 (VLA-4) on lymphocytes and monocytes (Dransfield et al; 1990).

E-selectin was previously known as endothelial leukocyte adhesion molecule-1 (ELAM-I). It is now clustered as CD62E according to the international workshop on human leukocyte differentiation antigens (Peakman and vergani; 1997). It is one of the selectin group of adhesion molecules regulating interaction of leukocytes and endothelial cells (Kansas; 1996). Circulating leukocyte binds to the selectins expressed by activated endothelium and thereby leukocyte migration occurs. Its principle ligand is sialyl lewis $\mathrm{x}$ blood group carbohydrate and is associated with CD 15 molecules present on leukocytes. It is the first inducible adhesive molecules to be demonstrated in the inflammatory process on the endothelial cells and has been found only on the endothelium (Cronstein and weissman; 1993). Soluble mediators of inflammation as IL-I, TNF- $\alpha$, endotoxin or substance $\mathrm{P}$ stimulate endothelial cells to synthesize and express E-selectin (Pober et al; 1986) which, like other adhesion molecules, is primarily found in soluble form after endothelial cell interaction (Carlos and Haralan; 1994). 
The objective of this study was to determine the serum concentrations of sTM, sVCAM-1, sICAM-1 and E-selectin in correlation with disease activity in Egyptian patients with SLE. In order to detect the most helpful one in assessment of the active stage of the disease.

\section{Patients and methods:-}

Sixty serum samples were collected from 40 patients (10 males and 30 females) attending rheumatology clinics at AlZahraa Hospital ,AL-AZHAR university, Cairo and a group of 20 normal volunteers as controls, from medical and laboratory staff (5 males and 15 females). The age of the patients and controls ranged between 16-60(38 \pm 15.0$)$ .None of the patients had a recent history of infection and were not receiving drugs except for non steroidal anti-inflammatory drugs and analgesics.

All samples were taken in the morning to avoid diurnal variations in the disease activity. All patients fulfilled the revised criteria of the American Rheumatisms Association (ARA).

\section{Assessment of disease activity:}

Disease activity was assessed using the British Isles Lupus Assessment Group (BILAG) activity index (Symmons et al; 1988) for SLE patients, an increased skin score (Brennan et al; 1992) and progressive organ involvement, and objective measurement of joint inflammation (tenderness and swelling). The assignment of active or inactive disease was made without knowledge of the adhesion molecules assay result.

The British Isles Lupus Assessment Group (BILAG) SLE activity score assesses current status and significant changes from the last clinical visit for 8 separate systembased groups. Disease activity is graded; A: active, requiring disease- modifying therapy; B: active but receiving symptomatic therapy only; C: stable; D: past involvement; $\mathrm{E}$ : system nerve involved. The index was not designed to provide global score per se. But in order to compare it with other activity indices, each grade was assigned a numerical value as follows, $\mathrm{A}=9, \mathrm{~B}=4, \mathrm{C}=1, \mathrm{D}$ and $\mathrm{E}=0$. Gladman and colleagues (1992) have shown correlations between BILAG scored in this way, systemic lupus activity measure (SLAM) and SLE disease activity index (SLEDAI) (Symmons et al; 1988). BILAG scoring system was used in the present study. Active patients were defined as those with at least one B grade and a total BILAG score $\geq 4$. According to the above criteria the 40 patients were divided into:

1. Group I: -Consists of 22 patients with active disease, having BILAG score $>10$. Their mean age was 16-60 (38 15.0$), 16$ females and 6 males.

2. Group II: -Consists of 18 patients with inactive disease, having BILAG score 0-5.

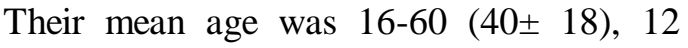
females and 6 males.

\section{Laboratory assessment:-}

Blood samples from patients and controls were collected.

Serum samples were assayed immediately for C-reactive protein (CRP) (SASTM-CRP latex- agglutination slide test), Rheumatoid factor (RF) (SASTMRF. latex agglutination slide test) and serum creatinine. Erythrocyte sedimentation rate (ESR) (Westergern). Total leukocytic count (TLC), platelet count (PC) (Coulter.s) and hemoglobin (HB) were done by using coulter counter (Micros). Serum samples from both patients and controls were stored at $-70^{\circ} \mathrm{c}$ for later determination of SICAM1, sVCAM-1, thrombomodulin and Eselectin.

\section{Immunoassay:-}

Concentrations of thrombomodulin, sVCAM-1, sICAM-1 and E-selectin were measured using commercially available kits for quantitative enzyme-linked immunosorbent assay (ELISA) (Diaclone Research, France). The tests were performed according to the manufacturer's instructions. These kits were solid phase sandwich ELISA. Monoclonal antibodies specific for each component has been coated onto 96well plates. Serum samples and standards of known concentration were pipetted into these wells. During the first incubation, antigen of each component and a biotinylated monoclonal antibody specific for each component were simultaneously incubated .After washing, the enzyme 
(streptavidin-peroxidase) was added .After incubation and washing to remove all the unbound enzyme, a substrate solution which acts on the bound enzyme was added to induce a colored reaction product. The intensity of this colored product is directly proportional to the concentrations of each component present in the samples. The intensity of the color of each well was measured by an automated ELISA plate reader at $450 \mathrm{~nm}$.

Statistical analyses : were carried out by students' $\mathrm{T}$ test .linear regression analysis was used to calculate correlation coefficients. Differences of variable between various data were evaluated with Wilcokons' test.

\section{Results:}

In this study, according to British Isles Lupus Assessment Group (BILAG) criteria the 40 patients were divided into two groups. The first included 22 with high disease activity (BILAG score>10). The second include 18 with low disease activity (BILAG score 0-5) .Results and statistical analysis were represented in tables 1-3.

In table (1): the mean values of thrombomodulin, sVCAM-1, sICAM-1 and E-selectin in all patients were $8.20 \pm 0.80$ $\mathrm{ng} / \mathrm{ml}, 550.0 \pm 55.0 \mathrm{u} / \mathrm{ml}, 34.0 \pm 1.2 \mathrm{u} / \mathrm{ml}$ and $44.50 \pm 5.30 \mathrm{ng} / \mathrm{ml}$ respectively. In active SLE group the mean values were12.8 \pm 2.20 $\mathrm{ng} / \mathrm{ml}, 650 \pm 60 \mathrm{ng} / \mathrm{ml}, 47.30 \pm 11.70 \mathrm{u} / \mathrm{ml}$ and $47.7 \pm 5.8 \mathrm{ng} / \mathrm{ml}$ respectively.

In the inactive SLE group, the mean values were $4.80 \pm 0.70 \mathrm{ng} / \mathrm{ml}, 430.0 \pm 29.0$ $\mathrm{u} / \mathrm{ml}, 27.9 \pm 8.5 \mathrm{u} / \mathrm{ml}$, and $45.7 \pm 5.0 \mathrm{ng} / \mathrm{ml}$ respectively (figs 1, 2, 3).

By comparing these values with those of the control group there was a very highly significant increase $(\mathrm{p}<0.0005)$ in both TM and sVCAM-1values, and moderate increase $(p<0.05)$ in sICAM1levels in active SLE.The inactive group showed mildly signifycant increase $(\mathrm{p}<0.05)$ for the three parameters. E-selectin values were insignificant $(p>0.05)$.

As summarized in table (2) the levels of sVCAM-1, sICAM-1 thromb-omodulin and E-selectin were correlated with ESR, TLC, CRP and platelet counts.

Values of sTM, sVCAM-1, sICAM1and E-selectin were significantly higher in $15 / 20$ patient with positive CRP (mean \pm SD) as compared to those with negative CRP as shown in table (2) and fig(5).

Table.3. represents correlation between British Isles Lupus Assessment Group (BILAG) score and laboratory parameters of disease activity.

There was a positive correlation between British Isles Lupus Assessment Group (BILAG) score and each of ESR and serum creatinine. Negative correlation was found with HB, TLC and platelet count, no significant correlation with CRP.

Table.1. Comparison between SLE patient groups and control as regards thrombomodulin, sVCAM- 1, sICAM- 1 and E-selectin values.

\begin{tabular}{|c|c|c|c|c|}
\hline & Control & All patients & Active & In active \\
\hline No. of samples & 20 & 40 & 22 & 18 \\
\hline $\begin{array}{l}\text { Thrombomodulin } \\
\text { ng/mL(mean } \pm \text { SD })\end{array}$ & $3.40 \pm 0.4$ & $\begin{array}{l}8.20 \pm 0.8 \\
p<0.0005\end{array}$ & $\begin{array}{l}12.80 \pm 2.20 \\
\mathrm{p}<0.0005\end{array}$ & $\begin{array}{l}4.80 \pm 0.7 \\
p<0.05\end{array}$ \\
\hline $\begin{array}{l}\text { sVCAM-1 } \quad \mathrm{u} / \mathrm{mL} \text { (mean } \\
\pm \mathrm{SD})\end{array}$ & $350.0 \pm 34.0$ & $\begin{array}{l}550.0 \pm 55 \\
p<0.0025\end{array}$ & $\begin{array}{l}650.0 \pm 60 \\
p<0.0005\end{array}$ & $\begin{array}{l}430.0 \pm 22 \\
p<0.05\end{array}$ \\
\hline sICAM-1 u/mL(mean \pm SD) & $7.40 \pm 1.80$ & $\begin{array}{l}34.0 \pm 1.2 \\
\mathrm{p}<0.05\end{array}$ & $\begin{array}{l}47.3 \pm 11.70 \\
p<0.05\end{array}$ & $\begin{array}{l}27.90 \pm 8.50 \\
p<0.05\end{array}$ \\
\hline $\begin{array}{l}\text { E-selectin } \quad \mathrm{ng} / \mathrm{mL}(\text { mean } \\
\pm \mathrm{SD})\end{array}$ & $38.40 \pm 4.0$ & $\begin{array}{l}44.50 \pm 5.30 \\
p>0.05\end{array}$ & $\begin{array}{l}47.0 \pm 5.80 \\
P>0.05\end{array}$ & $\begin{array}{l}45.70 \pm 5.0 \\
P>0.05\end{array}$ \\
\hline
\end{tabular}

$\mathrm{p}>0.05$ Non-significant difference.

$\mathrm{p}<0.05$ : significant correlation. 
Table.2.Correlation between sICAM, sVCAM, E-selectin and thrombomodulin values, clinical data and laboratory assessment of active and in active groups.

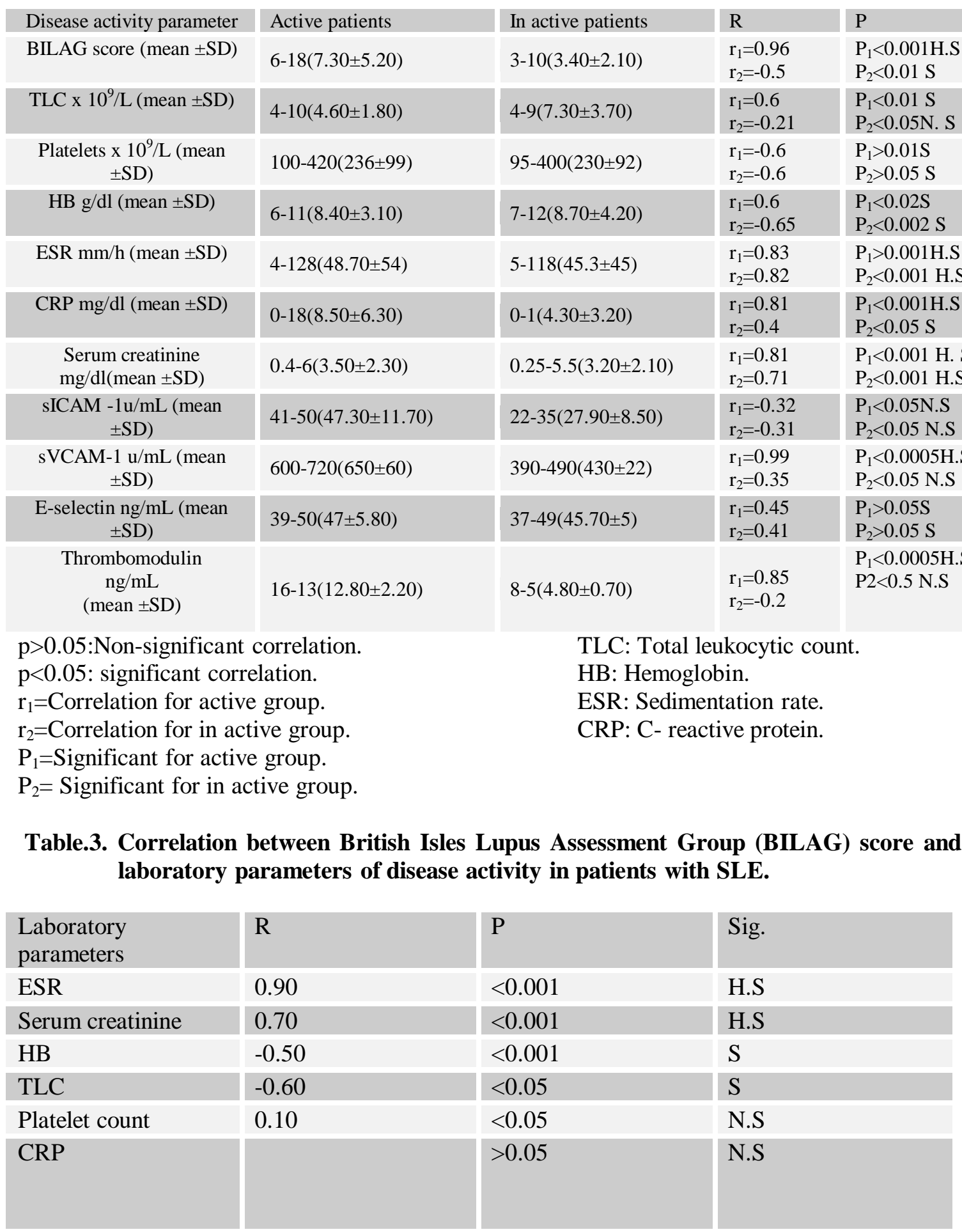




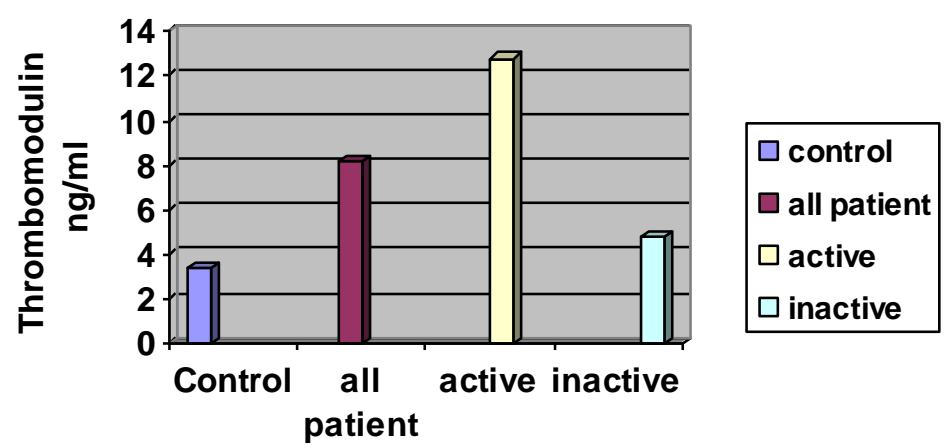

Fig.1.: comparison between thrombomodulin in patients and control group.

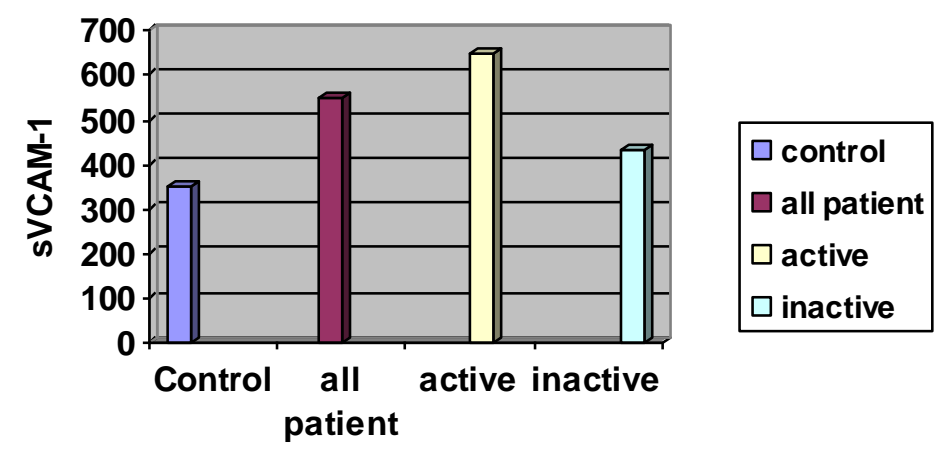

Fig.2.: comparison between sVCAM-1 in patients and control group.

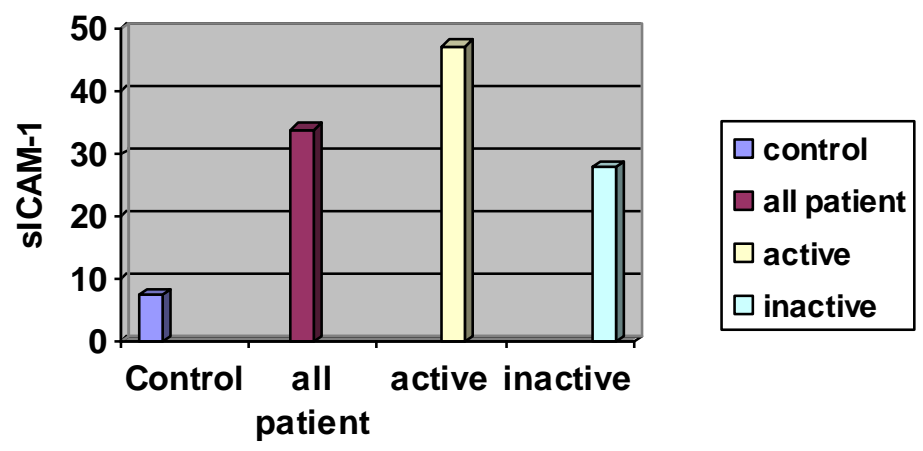

Fig.3.: comparison between sICAM-1 in patients and control group . 


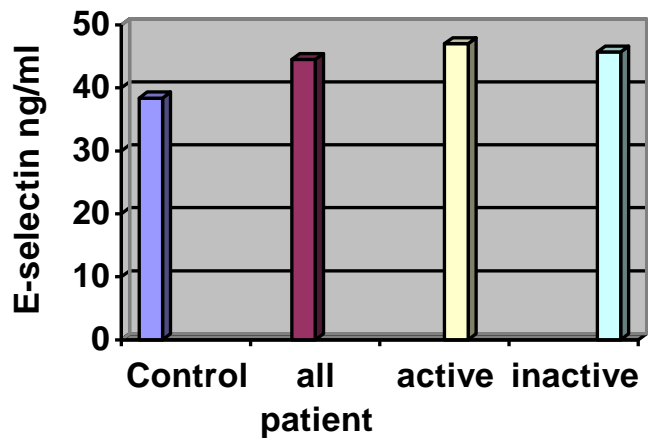

\begin{tabular}{|l|}
$\square$ control \\
$\square$ all patient \\
$\square$ active \\
$\square$ inactive
\end{tabular}

Fig.4.: comparison between E-selectin in patients and control group.
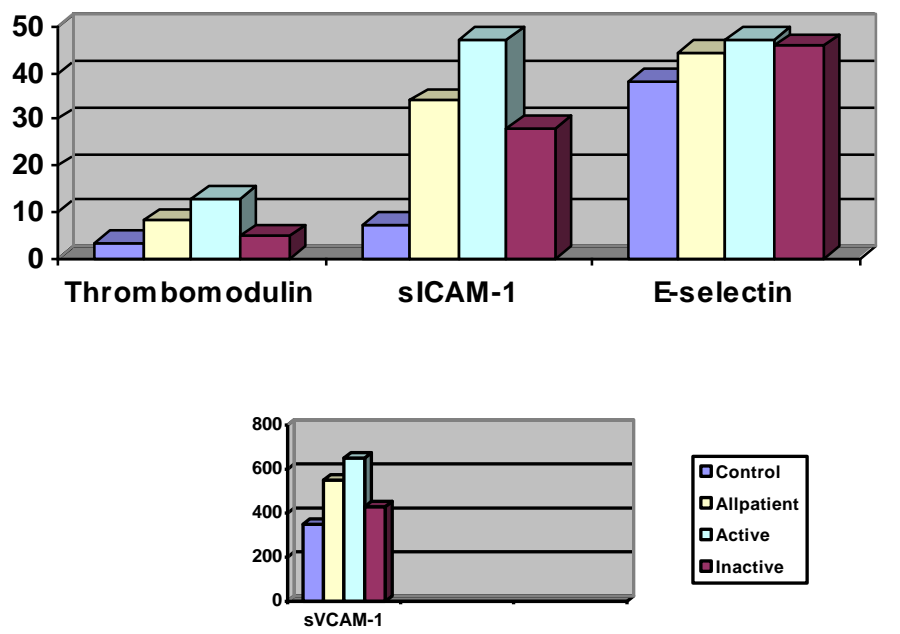

Fig.5.comparison between different groups of SLE and control group as regards level of adhesion molecules.

\section{Discussion:-}

SLE is characterized by immune complex vasculits with endothelial cell damage (Garcia - cozar et al; 1996). Also it has been suggested that expression of adhesion molecules primes the vascular endothelium for subsequent injury, as reflected by increased release of TM into the circulation (Boehme et al; 2000).SLE is characterized by considerable variation in disease manifestation, there -fore, reliable serological parameters of the inflammatory activity of the disease are required.
In this study the levels of sTM, sVCAM-1, sICAM-1 and E-selectin in serum were measured and correlated with disease activity in 40 patients, who were grouped into two groups, the first included 22 patients with active disease (BILAG $>10)$ and the second included 18 patients with low disease activity (BILAG 0-5).

The results demonstrated that the concentrations of serum STM in the active SLE patients (22/40) were significantly elevated when compared with the control 
group (20) ( $<<0.0005$,fig. 1.$)$, while in the inactive group (18/40) there was a slight increase in the concentration than in the control group ( $p<0.05$ tab.1-fig- 1$)$. This is because, within the inactive group some patients had low disease activity. Also a significant correlation was found between plasma sTM and BILAG activity index (table2) .This result provides evidence that plasma concentration of STM is an excellent serological parameter reflecting disease activity in patients with SLE.

This result agrees with other studies reported by Boehme et al; (1994), Kotajima et al; (1997), Kiraz et al; (1999), Boehme et al; ( 2000), Frijns et al; (2001) Horak et al; (2001) and Ho et al; (2003), who found that serum or plasma STM can be a reliable marker, with advantage over established serological parameters, to indicate disease activity. They also found significant correlation between plasma STM and disease activity indices, confirming that STM is a promising marker of SLE disease activity.

In the present study sVCAM-1values in the active group of SLE were significantly higher than in the control group ( $p<0.0005$ ) and were moderately elevated in the inactive group( $\mathrm{p}<0.05$ table.1 and fig.2).

sICAM-1 levels were significantly high in the both active and inactive groups with SLE than in the controls $(\mathrm{p}<0.05$ ,table.1 , fig 3). But E-selectin level was insignificant compared to the control group ( $>0.05$,table.1, fig.4). These results suggest that sVCAM-1 and sICAM-1, but not E-selectin can be useful in monitoring SLE activity. These results are in agreement with other studies. Janssen et al; (1994 ) studied soluble VCAM-1, ICAM -1 and Eselectin in relation to disease activity in SLE and found that SVCAM-1 correlated with disease activity in patients with SLE, being significantly higher during active compared with inactive disease $(\mathrm{p}=0.003)$, and normalizing with clinical remission. But soluble ICAM-I and E-selectin levels did not reflect disease activity.

Scudla et al; ( 1997) studied the role of sVCAM-1 in SLE and its relation to disease activity and there was significant relationship between serum levels of VCAM-I and disease activity that can be used in early diagnosis of exacerbation of the disease.

Egerer et al; ( 2000 )determined sEselectin and sICAM-1levels in SLE patients in comparison to patients with sepsis or infection. Elevated level of sE- selectin and sICAM-1 were detected in SLE in contrast to patients with localized infection( $\mathrm{p}<0.001)$. They concluded that combined elevation of sICAM-1 and sE-selectin correlate with the prognosis in patients with active SLE.

Sari et al; (2002) found a statistically significant positive correlation between sICAM-1 levels and SLE activity and no correlation was found between SICAM-1 and CRP and ESR and suggested that sICAM-1 may serve as serologic marker of disease activity.

However the results of Boehme et al ; (2000) did not agree with all of the above results as they found that there was a weak correlation between soluble adhesion molecule levels (ICAM-1, E-selectin and VCAM-1 ) and disease activity of SLE, but sTM was the most important serological parameter of disease activity .

The general indirect markers (ESR, CRP and TLC) showed moderate correlation with disease activity. No correlation was found with $\mathrm{HB}$ or platelet count .This is because these markers are influenced by a multiplicity of factors (Esdail et al ;1996)

In conclusion the present data suggest that STM is the best serological marker that reflects disease activity and may be used as a serological parameter for therapeutic considerations. On the other hand SVCAM1and sICAM-1 but not E-selectin seems to be promising, valuable serological disease activity markers in SLE. Further studies must be conducted to assess the clinical significance of these parameters.

\section{References:-}

1. Belmont HM,AminAR,Abrasmon Sb (1991):-Nitric oxide in systemic lupus erythematosus . In: Kammer GM, Tsokos GC, EDS.LUPUS:Molecular and Cellular 
pathogenesis.Totowa: Humana press,:2142.

2. Belmont HM,levartovshy D, Goel A et al .,(1997):-Increased nitric oxide production accompanied by the upregulation of inducible nitric oxide synthetase in vascular endothelium from patients with systemic lupus erythematosus.Arthritis Rheum 40:1810-6.

3. Bevialacqua MP ( 1993):-Endothelialleukocyte adhesion molecules. Ann. Rev. Immunol. 11:767.

4. Bochner BS, Klunk DA, sterbinsky et al, IL-I ( 1995):-selectivity includes vascular cell adhesion molecule-I expression in human endothelial cells.J.Immunol. 154:799 -803.

5. Boehme MWJ, Nawroth pp, Kling E ( 1994):- serum thrombomodulin. A novel marker of disease activity in systemic lupus erythematosus . Arthritis Rheum 37:572-7.

6. Boehme MWJ,Kaethu, galle pr, stremmel w, scherbaum WA ( 2000):serum thrombomodulin- a reliable marker of disease activity in systemic lupus erythematosus (SLE): advantage over established EXP. Immunol 119:189-95.

7. Brennan P.silman A.B.Ackc. Bemstein R, Coppock J.Maddision P.sheeranT., Stevens C, WollheimF (1992):- Reliability of skin involvement measures in scleroderma.Br J.Rheu -matol 31:457-60.

8. Carlos TM and Harlan JM (1994):leukocyte endothelial adhesion molecules. Blood 84:2068-2101.

9. Christiansen L. Sundstrom C Enblad G et al., (1998):-serum levels of soluble vascular cell adhesion molecule -1 (sVCAM-1) is an independent prognostic marker in Hodgkin's disease staging . Br. Hematol 102:701-709.

10. Cronstein BN, Reiss A, Malhortas (1999):- The vascular endothelium. Kammer GM, Tsokos GC,eds. lupus: Molecular and cellular pathogenesis. Totowa: Humana Press, ;13-20.

11. Cronstein Bc and weissmann G (1993):The adhesion molecules of inflammation. J Arthritis and Rheumatism, 36:147-152.

12. De fougerolles A, Stacker S, Schwartiny R, Springer T (1991) :- Characterization of ICAM-I and evidence for a third counter receptor for LFA-I.J.exp.Med;174:253-267.

13. Dittman WAand Majerus Pw (1990) :Structure and function of thrombomodulin, a natural anticoagulant blood, Blood, 75:329-336.
14. Dransfield I, Buckle A, Hoggn: ( 1990) Early events of the immune response mediated by leukocyte integrins. Immunol.Rev. 114-129.

15. Endo S, Inada K, Nakae $H$ et al (1995):blood levels of endothelin-I and thrombomodulin in patients with disseminated intravascular coagulation and sepsis.Res commun MOI pathol pharmacol 90:227-88.

16. Egerer K,Feist $\mathbf{E}$,Robr U,Pruss A, Burmester GR, DornerT(2000):Increased serum soluble CD14,ICAM-I and E-selectin correlate with disease activity and prognosis in systemic lupus erythematosus. Lupus 9(8):614-21.

17. EsdalJM.Abrahamowiecz M .Joseph L .et al; (1982):-Laboratory tests as pridectors of disease exacerbation in systemic lupus erythematosus.

18. Esmon NL, Owen WG, Esmon CT (1982):- Isolation of a membrane bound cofactor for thrombin-catalyzed activation of protein C.J Biochem 257:829-864.

19. Esmon CT, Owen WG (1996):Identification of an endothelial cell cofactor for thrombin catalyzed activation of protein C.proc.Natl Acad Sci USA 1981 ;78:224952.

20. Frijns R, Fijnheer R,Schiel A, Donders R et al (2001):-Persistent increase in plasma thrombomodulin in patient with a history of lupus nephritis: endothelial cell activation marker. J Rheumatology; 28:514-9

21. Garcia-Cozar FJ,Molina IJ, Cuadrado MJ et al (1996):-Defective B7 expression on antigen-presenting cells underlying $\mathrm{T}$ cell activation abnormalities in systemic lupus-erythematosus (SLE) patients. clin. EXP. Immunol ; 104:72-9.

22. Gearing AJ, Heming way $\mathbf{I}$, Pigott $\mathbf{R}$ et al (1992):- Soluble forms of vascular adhesion molecules, E-selectin, ICAMVCAM and I-I, pathological significa -nce. Ann. New York Acad. sci ;67:324-311.

23. Gladman D.D,Gladsmith C.H,U rowitz M.B., Bacon P. Bombarierc., Isenbergd., kalunian K., Liang M.H., Maddison P.,Nived O., Richter M., Snaith M., Symon SD., Zoma (1992):- A cross cultural validation and reliability of 3 disease activity indices in systemic lupus erthyematosus . J. Rematol,19:608-11

24. Ho,C.Y, Wong C.K,Li ${ }^{1}$.E.K, Tam ${ }^{1}$.L.S, and Lam C.W.K(2003):-Elevated plasma concentration of nitric oxide,soluble thrombomodulin and soluble vascular cell 


\section{Correlation of Serum Concentrations of Soluble.......}

adhesion molecule-1 inpatients with systemic lupus erythematosus.British Society for Rheumatology;42:117-122.

25. Horak $P$, Scul da $V$, Hermanova $Z$ (2001):- Clinical utility of selected disease activity markers in patients with systemic lupus erythematosus. Clin Rheumatol 20:337-44.

26. Ishii $H$, Uchiyama $H$ and Kazama $M$ (1991):-Soluble thrombomodulin antigen in conditioned medium is increased by damage of endothelial cells. Thromb Haemost. 65:618-623.

27. Ishii H, Nakano M, Tsubouchi J et al; (1990):-Establishment of enzyme immunoassay of human thrombo -modulin in plasma and urine using monoclonal antibodies .Thromb Haemost ;63:157-62.

28. Janssen BA,Luqmani RA, Gordon C, Hemingway IH, Bacon PA, Gearing AJ, Emery P (1994):-Correlation of Blood levels of soluble vascular cell adhesion molecule-1 with disease activity in systemic lupus erythematosus and vasculitis. $\mathrm{Br} \mathbf{J}$ Rheumatol. ;33 (12):11112-6.

29. Juneja H, Schmalsterg F, Chen J (1993) :- vascular cell adhesion molecule -1 and VLA-4 are obligatory adhesion proteins in the heterotypic adherence between lymphoma cell and marrow stromal cells .J. exp.Hematol. 21:224-450.

30. Kansas Gs: Selectins and their ligands (1996:-) Current concepts and controversies: Blood, 88:3259.

31. KofflerD(1974): Immunopathogenesis of systemic lupus erythematosus. Ann. Med.25:149-64.

32. Kiraz S,. Ertenli I; Benekli, M. et al (1999):-Clinical significance of hemostatic markers and thrombom -odulin in renal disease : Lupus;87:134-40.

33. Kotajima L, Aotsuka S, SataoT (1997):Clinical significance of serum thrombomodulin levels in patients with systemic rheumatic diseases.Clin.exp. Rheumatol ; 15:59-65.

34. Ohdama S,Takano S,Miyake S, KubotaT,SatoK,Aoki N( 1994):-Plasma thrombomodulin as a marker of vascular injuries in collagen vascular disease.Am J clin pathol 101:109-13.
35. Peakman M and Vergani D (1997):Adhesion molecules.In Britton and Danielson (ed):Basic and clinical imm unology. Churchill Livingotone. 24.

36. Prober Js, Beviacqua, Mendrick DL, Lapierre LA, Fiers W and Ginbrore MA (1986):- Two distinct monokines, interleukin I and tumor necrosis factor, each independently induce biosynthesis and transient expression of the same antigen on the surface of cultured human vascular endothelial cells. J Immunol; 136:1680.

37. Sari RA,Taysi S, Erdem F,Yilmaz O, Keleses S, Kiziltune A, Odabas AR, Cetinkaya R (2002) :-Correlation of serum levels of soluble intercellular adhesion molecule-I with disease activity in systemic lupus erthematosus. Rheumatol Int;.J :21(4):149-52.

38. Scarpati EM and Sadler Je(1990):Regulation of endothelial cell coagulant properties :Modulation of tissue factor, plasminogen activator inhibitors and thrombomodulin by phorbol 12-myristate 13- acetate and tumor necrosis factor.J.Biol chem,264:207.

39. Scudla V,Horak P,Fatlynek L, Pospisil Z, Budi Kova M, Hermanova Z (1997):vascular intercellular adhesive molecule I(VCAM-1)-a new indicator of activity in systemic lupus erythematosus. Vnitr lek;34(5):307-11.

40. Springer TA (1994):-Traffic signals for lymphocyte recirculation and leukocyte emigration: The multistep paradigm.Cell; 79:301-14.

41. Symmons D.P.M.,Coppock J.s.Bacon P.A.,Bresnihan B., Isnberg D.A., Maddision P. Mchugh N., Snatth M.I., Zoma A.S (1988):-Development and assessment of a computerized index of clinical disease activity in systemic lupus erythematosus.Q J Med;69:927-37.

42. Tsukada N, Matsuda M, Miyagi K, Yanagisawa N (1995):-Thromomodulin in the sera of patients with multiple sclerosis and human lymphotropic virus type-1associated myleopathy.J Neuroimmunol 56:113-6. 
تر ابط مستوى الثرومبوموديولين وجزيئات الالتصاق الذائبه

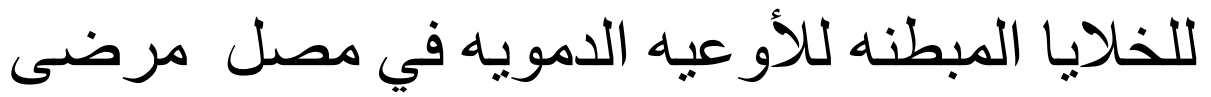
الذئبه الحمر اء الاء

\section{ملكه علي محمد محسن, ماجدة عبد المنعم جميل*, مها إبراهيم شحاتة *,

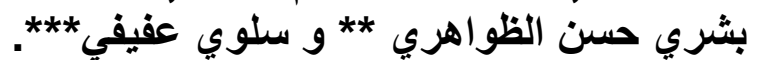

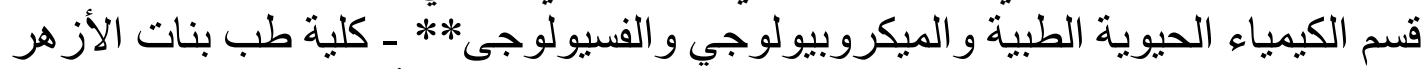

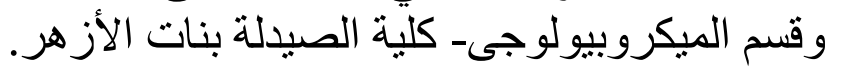

في هذا البحث تم تقيهم مستوي جزيئات الألتصـاق الذائبه للخلايـا المبطنه الأوعيـه الدمويه (ايكام-1 الذائب فيكام-1 الذائب و اسلكتين الذائب و الثرمبوموديولين) في مصل 40 مريض مصابين بمرض التييس المجمو عي بالأضافة الي 20 شخصا كمجمو عة ضابطة وقئ

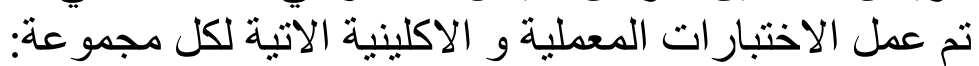

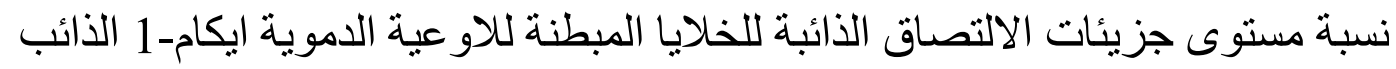

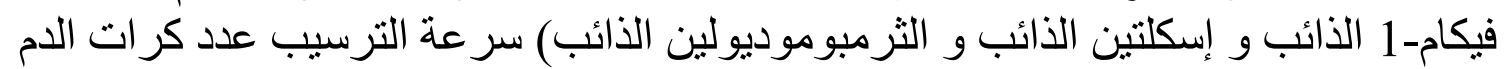

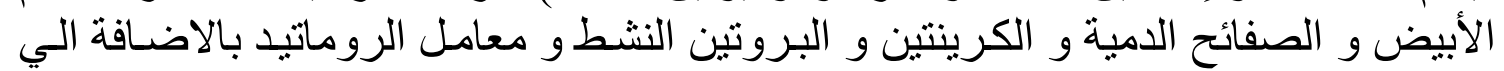
اعر اض نشاط المرض الاكلينيكية مثل التهاب المفاصل و الكلى و العضلات و الرئة و الجلد

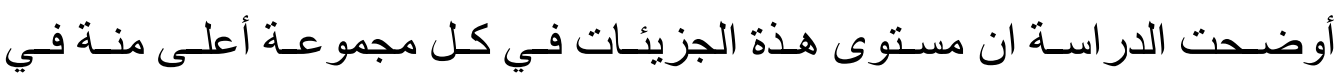

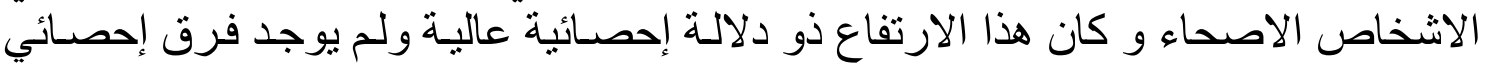
في مستوى ايكام-1الذائب و فيكام-1 الذائب الأبن.

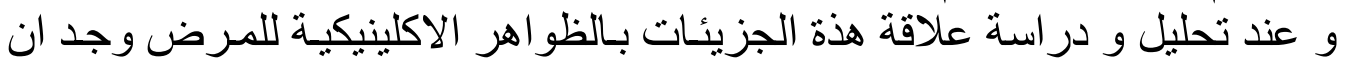

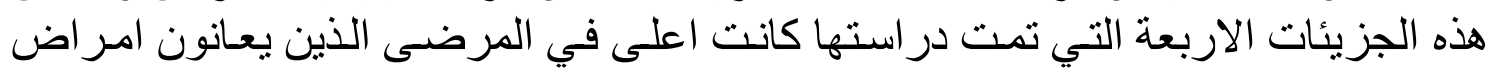
الانسجة الضامة.

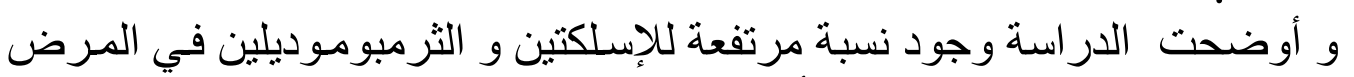

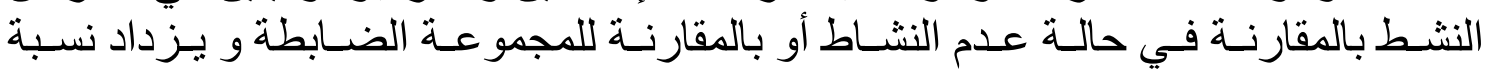

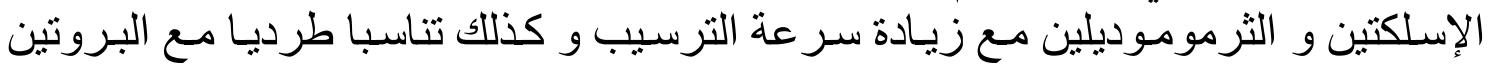
النشط في مرض الانسجة الضامة (الذئبه الحمر اء).

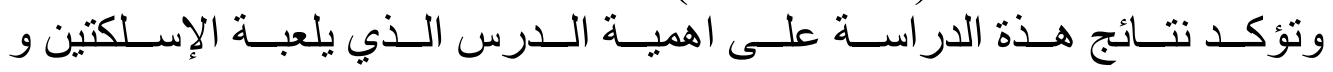

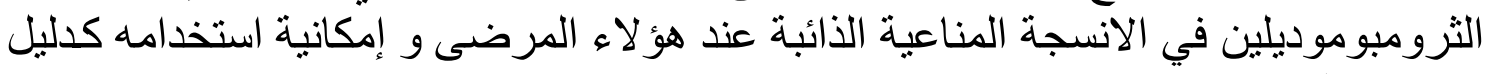

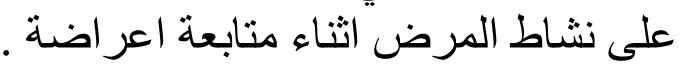

